\title{
Variability in concentrations of potentially toxic elements in urban parks from six European cities
}

\author{
L. Madrid, ${ }^{* a}$ E. Diaz-Barrientos,${ }^{a}$ E. Ruiz-Cortés, ${ }^{a}$ R. Reinoso, ${ }^{a}$ M. Biasioli, ${ }^{b}$ \\ C. M. Davidson,${ }^{f}$ A. C. Duarte, ${ }^{d}$ H. Grčman, ${ }^{g}$ I. Hossack, ${ }^{c}$ A. S. Hursthouse, ${ }^{c}$ \\ T. Kralj, ${ }^{g}$ K. Ljung, ${ }^{e}$ E. Otabbong, ${ }^{e}$ S. Rodrigues, ${ }^{d}$ G. J. Urquhart ${ }^{f}$ and \\ F. Ajmone-Marsan ${ }^{b}$
}

Received 6th June 2006, Accepted 11th September 2006

First published as an Advance Article on the web 26th September 2006

DOI: $10.1039 / \mathrm{b} 607980 f$

Use of a harmonised sampling regime has allowed comparison of concentrations of copper, chromium, nickel, lead and zinc in six urban parks located in different European cities differing markedly in their climate and industrial history. Wide concentrations ranges were found for copper, lead and zinc at most sites, but for chromium and nickel a wide range was only seen in the Italian park, where levels were also considerably greater than in other soils. As might be expected, the soils from older cities with a legacy of heavy manufacturing industry (Glasgow, Torino) were richest in potentially toxic elements (PTEs); soils from Ljubljana, Sevilla and Uppsala had intermediate metal contents, and soils from the most recently established park, in the least industrialised city (Aveiro), displayed lowest concentrations. When principal component analysis was applied to the data, associations were revealed between $\mathrm{pH}$ and organic carbon content; and between all five PTEs. When $\mathrm{pH}$ and organic carbon content were excluded from the PCA, a distinction became clear between copper, lead and zinc (the "urban" metals) on the one hand, and chromium and nickel on the other. Similar results were obtained for the surface (0-10 cm depth) and sub-surface (10-20 cm depth) samples. Comparisons with target or limit concentrations were limited by the existence of different legislation in different countries and the fact that few guidelines deal specifically with public-access urban soils intended for recreational use.

\section{Introduction}

Soil quality is currently a topic of considerable importance in Europe, as consultation progresses on development of a Thematic Strategy on the Protection of Soil under the 6th Environmental Action Programme of the European Community. ${ }^{1}$ Urban soils are of interest for a number of reasons. Although of marginal significance for the production of food, they contribute significantly to the quality of the urban environment. They are generally less well characterised than agricultural soils, ${ }^{2}$ and are highly spatially variable due to diverse human activities that influence soil composition. ${ }^{3}$ These include the addition of waste materials, pollution from numerous point and diffuse sources, landscaping, and rapid

\footnotetext{
${ }^{a}$ Instituto de Recursos Naturales y Agrobiología de Sevilla (CSIC), Apartado 1052, Sevilla,41080, Spain.E-mail: madrid@irnase.csic.es

${ }^{b}$ DI.VA.P.R.A., Chimica Agraria, Università di Torino, Via Leonardo da Vinci, 44, Grugliasco Torino, 10095, Italy

${ }^{c}$ School of Engineering \& Science, University of Paisley, High Street, Paisley, Scotland, UK

${ }^{d}$ Departamento de Química, Universidade de Aveiro, Aveiro, 3810193, Portugal

${ }^{e}$ Swedish University of Agricultural Sciences, Department of Soil Sciences, P.O. Box 7014, Uppsala, SE-750 07, Sweden

${ }^{f}$ Department of Pure \& Applied Chemistry, University of Strathclyde,

295 Cathedral St., Glasgow, Scotland, UK G1 1 XL

${ }^{g}$ Univerza v Ljubljani, Biotehniska fakulteta, Ljubljana, 1000, Slovenia
}

changes of land-use, which, together, can modify soil properties in an unpredictable manner. The presence of enhanced levels of toxic chemical substances in urban soils - especially in public-access areas such as parks and gardens - is a cause for concern since pollutants can be easily transferred to humans through suspended matter or by direct contact with the soil. ${ }^{4}$

Interest in the urban geochemistry of potentially toxic elements (PTEs) has expanded rapidly in recent years ${ }^{5}$ with studies conducted in several European cities including Stockholm $^{6}$ (Sweden), Palermo ${ }^{7}$ and Naples ${ }^{8}$ (Italy), Pozman ${ }^{9}$ (Poland), Sevilla ${ }^{10}$ (Spain) and Jackobstad ${ }^{11}$ (Finland). However, lack of harmonisation in procedures for urban soil sampling and PTE determination, together with the intrinsic variability in composition of urban soils, ${ }^{12-14}$ make comparison between studies difficult.

The EU URBSOIL project is aimed at assessing the role of urban soils as a source and sink for pollutants. The initial stage of the project, which is described here, involved collection of soil samples, by means of a harmonised sampling regime, from a public park in each of six European cities, and characterisation of the soil samples. The parameters measured were $\mathrm{pH}$, organic carbon content, and the concentrations of five PTEs: chromium, copper, nickel, lead and zinc. The aims of the work were to evaluate the short-range spatial variability in soil composition within each site, to compare data from parks in different cities and to explore by means of 
principal component analysis (PCA) relationships between analytes that are common to all cities.

\section{Experimental}

\section{Description of sites}

Sites with a common land-use - a visually homogeneous park or area therein - were selected in each city. Parks were selected based on their relatively central position within the city. They were as far as possible from current point sources of pollution, such as industrial emissions, but all were bordered by major roads and are thus likely to be affected by vehicle emissions. No agronomic activities exist in any of the sites chosen, and only conventional maintenance operations, such as mowing or irrigation, are normally carried out. Information on the sampling sites is given in Table 1 .

\section{Sampling}

A sampling grid of at least 25 points $(50 \times 50 \mathrm{~m}$ apart $)$ was defined at each site, with the exception of Glasgow. Here, geophysical data obtained after selection of site GL1 indicated that large areas of Glasgow Green contained subterranean structures (e.g. WWII public air raid shelters) and specific sources of contaminant (e.g. a partially-constructed swimming pool later in-filled with coal tar waste) ${ }^{15}$ For this reason, a second site, GL2, was selected in this city, and approximately half the samples were collected from each park (neither having sufficient undisturbed open green space to accommodate the entire sampling grid). The Ljubljana and Torino samples were obtained from parks considerably larger than the sampling area and so a regular grid could be applied. The external shape and vertex spacing of the sampling points in Aveiro, Sevilla and Uppsala were distorted slightly to fit the dimensions of the sampling site and avoid obstacles such as pedestrian paths and playgrounds. A particular problem in Sevilla is that paths and play areas are generally covered with an earthy, calcareous material ("albero"). Sampling of this material was avoided.
To assess the vertical distribution of soil parameters, two depths were sampled at each point: a surface sample (SF) at 0-10 $\mathrm{cm}$ and a sub-surface sample (SB) at 10-20 cm. Samples were collected with a trowel or (plastic-lined) corer. Apparatus was cleaned between sampling points.

\section{Sample preparation and analysis}

Soils were air-dried then passed through a $2 \mathrm{~mm}$ sieve. A subsample was then taken and ground to $<150 \mu \mathrm{m}$ particle size by means of an agate mill or mortar. Soil $\mathrm{pH}$ was determined in $0.01 \mathrm{M} \mathrm{CaCl}_{2}$ on the $<2 \mathrm{~mm}$ particle size fraction. ${ }^{16}$ Organic matter was determined by the $\mathrm{K}_{2} \mathrm{Cr}_{2} \mathrm{O}_{7}$ method ${ }^{17}$ in Ljubljana, Sevilla and Torino, but samples from Aveiro, Glasgow and Uppsala were subjected to CHNS microanalysis and the organic $\mathrm{C}$ content estimated following correction for carbonate content. To investigate whether results obtained by the two analytical methods were related, a set of urban soils of variable organic $\mathrm{C}$ content (from 1 to $10 \%$ ) were subjected to both potassium dichromate treatment and microanalysis. A highly significant correlation was found between the results of the two methods $(r=0.9513, P \ll 0.001)^{18}$ and so the following equation, calculated for the reduced major axis of the corresponding plot, was used to convert results obtained by microanalysis to equivalent, dichromate-based, values, thus allowing comparison between sites in different cities:

$$
(\text { CHNS data })=1.007 \times(\text { dichromate data })-0.269
$$

Specimens of the $<150 \mu \mathrm{m}$ particle size fraction were subjected to closed microwave, aqua regia digestion to assess their pseudototal metal content. Soil digests were analysed by flame atomic absorption spectrometry, inductively-coupled plasma atomic emission spectrometry or inductively-coupled plasma mass spectrometry, depending on instrument availability in the participant laboratories. Each laboratory included relevant blanks, replicates, and certified reference materials (BCR CRMs 141R, 142R, 143R and soils associated with the Wageningen Evaluation Programme for Analytical

Table 1 General information on the cities studied and sampling sites

\begin{tabular}{|c|c|c|c|c|c|c|c|}
\hline Site & City & $\begin{array}{l}\text { Approximate } \\
\text { population }\end{array}$ & $\begin{array}{l}\text { Mean annual } \\
\text { temperature } \\
\text { and rainfall }\end{array}$ & Name & Site description & $\begin{array}{l}\text { Approximate age } \\
\text { or history of site }\end{array}$ & $\begin{array}{l}\text { No. of } \\
\text { sampling } \\
\text { points }\end{array}$ \\
\hline AVE & $\begin{array}{l}\text { Aveiro } \\
\text { (Portugal) }\end{array}$ & 70000 & $18^{\circ} \mathrm{C} / 1000 \mathrm{~mm}$ & Park Galitos & $\begin{array}{l}\text { Maintained ornamental } \\
\text { park, } \sim 75 \mathrm{~m} \text { from railway } \\
\text { and small canal }\end{array}$ & $<10$ years & 26 \\
\hline GL1 & $\begin{array}{l}\text { Glasgow } \\
\text { (UK) }\end{array}$ & 600000 & $8.9^{\circ} \mathrm{C} / 900 \mathrm{~mm}$ & Glasgow Green & $\begin{array}{l}\text { Grass cover and well- } \\
\text { established trees, bordering } \\
\text { the River Clyde; }\end{array}$ & $\begin{array}{l}\text { Medieval common grazing } \\
\text { land, gifted to the people of } \\
\text { Glasgow in } 1450\end{array}$ & 13 \\
\hline GL2 & $\begin{array}{l}\text { Glasgow } \\
(\mathrm{UK})\end{array}$ & & & Alexandra Park & Grass cover & $\begin{array}{l}\text { Open land re-developed as a } \\
\text { park in } 1870\end{array}$ & 14 \\
\hline LJU & $\begin{array}{l}\text { Ljubljana } \\
\text { (Slovenia) }\end{array}$ & 270000 & $10^{\circ} \mathrm{C} / 1400 \mathrm{~mm}$ & Park Tivoli & $\begin{array}{l}\text { Maintained ornamental } \\
\text { park close to railway }\end{array}$ & $\begin{array}{l}\text { Mansion house grounds since } \\
\text { 18th century, most recently re- } \\
\text { developed in } 1913 \text {. }\end{array}$ & 25 \\
\hline SEV & $\begin{array}{l}\text { Sevilla } \\
\text { (Spain) }\end{array}$ & 710000 & $18{ }^{\circ} \mathrm{C} / 540 \mathrm{~mm}$ & $\begin{array}{l}\text { Parque de los } \\
\text { Principes }\end{array}$ & $\begin{array}{l}\text { Maintained ornamental } \\
\text { park }\end{array}$ & $\sim 40$ years & 32 \\
\hline TOR & $\begin{array}{l}\text { Torino } \\
\text { (Italy) }\end{array}$ & 900000 & $13^{\circ} \mathrm{C} / 750 \mathrm{~mm}$ & Parco del Valentino & $\begin{array}{l}\text { Grass cover and trees, } \\
\text { bordering the River Po }\end{array}$ & $\sim 400$ years & 25 \\
\hline UPP & $\begin{array}{l}\text { Uppsala } \\
\text { (Sweden) }\end{array}$ & 190000 & $5.6^{\circ} \mathrm{C} / 550$ & Stadstradgarden & $\begin{array}{l}\text { Maintained ornamental } \\
\text { park, bordering the River } \\
\text { Fyris }\end{array}$ & $\begin{array}{l}\text { Medieval agricultural and } \\
\text { grazing land, re-developed in } \\
1830 \text {. }\end{array}$ & 25 \\
\hline
\end{tabular}


Laboratories (WEPAL)) in their analyses. Almost all results obtained were within three standard deviations of relevant certified or indicative values. In addition, a set of urban soil secondary reference material were prepared and exchanged between partners to assess comparability of results generated in different countries. The majority $(>80 \%)$ of analyses reported for these soils were within $25 \%$ of target values. ${ }^{19}$ Reagents used in the study were of analytical grade (or better), distilled (or de-ionised) water was used throughout, and all laboratory-ware was acid-washed and rinsed with distilled water before use.

\section{Statistical analysis}

Data analysis was performed by use of the statistical package SPSS v.12.01 (SPSS Inc., Chicago, IL, USA).

\section{Results and discussion}

\section{Within-site variability}

Tables 2 and 3 summarise the results obtained for analysis of the SF and SB samples from each site, and present results of some statistical analysis. Most sites and depths were homogeneous in terms of their $\mathrm{pH}$, but organic carbon content showed quite noticeable variability (RSD $>40 \%$ for the number of points specified in Table 1) in GL1 (SF), TOR (SF) and GL2 (SB). Within each site, the ranges in the concentrations of PTEs were often wide. This most probably reflects the diverse, intermittent and long-term, effects of human activities (waste disposal, amendments, traffic etc.) on the urban environment, which can cause highly localised variations in metal concentrations. There was marked variability in levels of copper, lead and zinc at most sites, with frequent

Table 2 Summary of results for the SF $(0-10 \mathrm{~cm})$ samples of all the cities

\begin{tabular}{|c|c|c|c|c|c|c|c|c|}
\hline City & Variable & $\mathrm{pH}$ & $\mathrm{C}_{\text {org }}(\%)$ & $\mathrm{Cr} / \mathrm{mg} \mathrm{kg}^{-1}$ & $\mathrm{Ni} / \mathrm{mg} \mathrm{kg}^{-1}$ & $\mathrm{~Pb} / \mathrm{mg} \mathrm{kg}^{-1}$ & $\mathrm{Zn} / \mathrm{mg} \mathrm{kg}^{-1}$ & $\mathrm{Cu} / \mathrm{mg} \mathrm{kg}^{-1}$ \\
\hline \multirow[t]{7}{*}{ AVE } & Mean & 6.7 & 1.5 & 10 & 11 & 20 & 46 & 18 \\
\hline & Median & 6.7 & 1.4 & 10 & 9.0 & 20 & 49 & 16 \\
\hline & St. dev. & 0.6 & 0.4 & 2.0 & 6.0 & 7.0 & 15 & 11 \\
\hline & Max. & 7.7 & 2.5 & 15 & 28 & 38 & 82 & 61 \\
\hline & Min. & 5.0 & 0.9 & 6.0 & 6.0 & 7.0 & 18 & 8.0 \\
\hline & Skewness & -0.9 & 0.8 & 0.1 & 2.0 & 0.5 & 0.3 & 2.6 \\
\hline & Kurtosis & 1.9 & 0.2 & 0.0 & 3.6 & 1.0 & 0.7 & 9.0 \\
\hline \multirow[t]{7}{*}{ GL1 } & Mean & 5.2 & 5.1 & 29 & 35 & 307 & 199 & 85 \\
\hline & Median & 5.3 & 4.8 & 30 & 33 & 279 & 174 & 88 \\
\hline & St. dev. & 0.4 & 2.4 & 4.0 & 9.0 & 146 & 81 & 23 \\
\hline & Max. & 5.7 & 10.9 & 34 & 53 & 676 & 377 & 113 \\
\hline & Min. & 4.5 & 2.3 & 24 & 21 & 98 & 102 & 24 \\
\hline & Skewness & -0.6 & 1.2 & -0.1 & 0.5 & 1.3 & 1.1 & -1.6 \\
\hline & Kurtosis & -0.9 & 1.8 & -1.7 & -0.3 & 2.5 & 0.5 & 3.8 \\
\hline \multirow[t]{7}{*}{ GL2 } & Mean & 4.3 & 6.0 & 45 & 29 & 194 & 122 & 62 \\
\hline & Median & 4.1 & 6.1 & 40 & 26 & 179 & 104 & 59 \\
\hline & St. dev. & 0.5 & 1.4 & 27 & 10 & 71 & 65 & 20 \\
\hline & Max. & 5.5 & 7.9 & 131 & 53 & 414 & 305 & 113 \\
\hline & Min. & 3.9 & 4.3 & 21 & 18 & 114 & 67 & 33 \\
\hline & Skewness & 1.5 & 0.2 & 2.7 & 1.3 & 2.4 & 2.2 & 1.1 \\
\hline & Kurtosis & 2.0 & -1.5 & 8.8 & 1.4 & 7.5 & 4.6 & 1.8 \\
\hline \multirow[t]{7}{*}{ LJU } & Mean & 6.8 & 5.6 & 21 & 22 & 78 & 114 & 33 \\
\hline & Median & 6.9 & 5.4 & 20 & 23 & 72 & 103 & 31 \\
\hline & St. dev. & 0.3 & 1.1 & 6.0 & 6.0 & 37 & 42 & 12 \\
\hline & Max. & 7.2 & 8.1 & 33 & 43 & 225 & 300 & 78 \\
\hline & Min. & 6.0 & 3.5 & 13 & 15 & 39 & 84 & 21 \\
\hline & Skewness & -0.8 & 0.5 & 0.4 & 1.9 & 2.7 & 3.9 & 2.4 \\
\hline & Kurtosis & 0.5 & 0.1 & -0.9 & 5.7 & 10.4 & 17.2 & 7.5 \\
\hline \multirow[t]{7}{*}{ SEV } & Mean & 7.0 & 2.5 & 36 & 29 & 107 & 107 & 48 \\
\hline & Median & 7.1 & 2.6 & 37 & 28 & 100 & 99 & 47 \\
\hline & St. dev. & 0.2 & 0.6 & 7.0 & 4.0 & 48.4 & 28.9 & 10.9 \\
\hline & Max. & 7.2 & 3.3 & 51 & 37 & 247 & 191 & 72 \\
\hline & Min. & 6.4 & 0.3 & 21 & 21 & 43 & 73 & 30 \\
\hline & Skewness & -1.8 & -1.7 & -0.4 & 0.2 & 1.3 & 1.5 & 0.5 \\
\hline & Kurtosis & 3.9 & 5.5 & 0.1 & -0.5 & 1.7 & 2.4 & -0.4 \\
\hline \multirow[t]{7}{*}{ TOR } & Mean & 6.5 & 2.7 & 188 & 207 & 144 & 225 & 87 \\
\hline & Median & 6.7 & 2.2 & 177 & 195 & 137 & 234 & 83 \\
\hline & St. dev. & 0.7 & 1.2 & 41 & 43 & 50 & 57 & 20 \\
\hline & Max. & 7.3 & 5.4 & 288 & 315 & 257 & 317 & 123 \\
\hline & Min. & 4.9 & 0.9 & 150 & 154 & 68 & 116 & 44 \\
\hline & Skewness & -0.8 & 0.9 & 1.5 & 1.1 & 0.4 & -0.4 & 0.1 \\
\hline & Kurtosis & 0.2 & -0.1 & 1.4 & 0.7 & -0.1 & -0.8 & -0.4 \\
\hline \multirow[t]{7}{*}{ UPP } & Mean & 6.6 & 3.7 & 36 & 22 & 47 & 112 & 36 \\
\hline & Median & 6.6 & 3.7 & 35 & 21 & 36 & 106 & 31 \\
\hline & St. dev. & 0.4 & 1.1 & 10 & 7.0 & 24 & 36 & 17 \\
\hline & Max. & 7.6 & 5.9 & 56 & 34 & 116 & 193 & 90 \\
\hline & Min. & 5.8 & 0.2 & 12 & 7.0 & 7.0 & 27 & 8.0 \\
\hline & Skewness & 0.1 & -1.0 & -0.5 & 0.0 & 1.0 & 0.2 & 1.5 \\
\hline & Kurtosis & 0.1 & 2.8 & 1.3 & 0.1 & 1.5 & 0.8 & 3.4 \\
\hline
\end{tabular}


Table 3 Summary of results for the SB $(10-20 \mathrm{~cm})$ samples of all the cities

\begin{tabular}{|c|c|c|c|c|c|c|c|c|}
\hline City & Variable & $\mathrm{pH}$ & $\mathrm{C}_{\text {org }}(\%)$ & $\mathrm{Cr} / \mathrm{mg} \mathrm{kg}^{-1}$ & $\mathrm{Ni} / \mathrm{mg} \mathrm{kg}^{-1}$ & $\mathrm{~Pb} / \mathrm{mg} \mathrm{kg}^{-1}$ & $\mathrm{Zn} / \mathrm{mg} \mathrm{kg}^{-1}$ & $\mathrm{Cu} / \mathrm{mg} \mathrm{kg}^{-1}$ \\
\hline \multirow[t]{7}{*}{ AVE } & Mean & 6.9 & 1.2 & 10 & 10 & 21 & 54 & 14 \\
\hline & Median & 7.1 & 1.1 & 10 & 9.0 & 19 & 48 & 13 \\
\hline & St. dev. & 0.7 & 0.3 & 3.0 & 3.0 & 8.0 & 24 & 6.0 \\
\hline & Max. & 7.7 & 2.0 & 16 & 19 & 41 & 134 & 33 \\
\hline & Min. & 5.0 & 1.0 & 6.0 & 6.0 & 10 & 28 & 7.0 \\
\hline & Skewness & -1.2 & 1.0 & 0.5 & 1.6 & 0.8 & 1.9 & 1.6 \\
\hline & Kurtosis & 1.7 & 1.0 & -0.3 & 3.8 & 0.3 & 5.0 & 2.9 \\
\hline \multirow[t]{7}{*}{ GL1 } & Mean & 5.3 & 6.2 & 28 & 36 & 330 & 196 & 134 \\
\hline & Median & 5.5 & 6.6 & 28 & 38 & 314 & 200 & 99 \\
\hline & St. dev. & 0.5 & 1.9 & 3.0 & 8.0 & 197 & 67 & 174 \\
\hline & Max. & 6.0 & 9.0 & 33 & 51 & 894 & 317 & 678 \\
\hline & Min. & 4.2 & 3.1 & 23 & 25 & 143 & 94 & 34 \\
\hline & Skewness & -1.0 & -0.4 & 0.0 & 0.1 & 2.3 & 0.0 & 3.3 \\
\hline & Kurtosis & 1.5 & -0.6 & -0.1 & -0.5 & 6.8 & -0.4 & 11.3 \\
\hline \multirow[t]{7}{*}{ GL2 } & Mean & 4.4 & 3.8 & 32 & 24 & 142 & 125 & 51 \\
\hline & Median & 4.3 & 3.4 & 22 & 21 & 130 & 115 & 43 \\
\hline & St. dev. & 0.6 & 1.7 & 25 & 7.0 & 90 & 60 & 31 \\
\hline & Max. & 5.9 & 8.4 & 107 & 39 & 432 & 298 & 152 \\
\hline & Min. & 4.0 & 1.6 & 17 & 16 & 41 & 64 & 24 \\
\hline & Skewness & 2.1 & 1.6 & 2.5 & 1.2 & 2.7 & 1.9 & 3.1 \\
\hline & Kurtosis & 3.3 & 3.8 & 6.3 & 0.3 & 9.4 & 4.8 & 10.9 \\
\hline \multirow[t]{7}{*}{ LJU } & Mean & 6.9 & 4.0 & 21 & 22 & 79 & 113 & 35 \\
\hline & Median & 7.0 & 4.1 & 21 & 20 & 77 & 101 & 32 \\
\hline & St. dev. & 0.3 & 0.9 & 5.0 & 4.0 & 39 & 42 & 16 \\
\hline & Max. & 7.2 & 6.6 & 34 & 31 & 223 & 301 & 101 \\
\hline & Min. & 6.1 & 2.2 & 11 & 15 & 35 & 81 & 20 \\
\hline & Skewness & -1.5 & 0.7 & 0.3 & 0.5 & 2.2 & 3.9 & 3.3 \\
\hline & Kurtosis & 2.6 & 1.5 & -0.1 & 0.1 & 6.9 & 17.3 & 13.7 \\
\hline \multirow[t]{7}{*}{ SEV } & Mean & 7.1 & 1.5 & 36 & 29 & 112 & 96 & 48 \\
\hline & Median & 7.1 & 1.5 & 34 & 29 & 99 & 88 & 45 \\
\hline & St. dev. & 0.1 & 0.4 & 7.7 & 3.5 & 54.5 & 21 & 14 \\
\hline & Max. & 7.2 & 2.7 & 50 & 34 & 265 & 158 & 86 \\
\hline & Min. & 6.6 & 0.8 & 19 & 21 & 40 & 69 & 31 \\
\hline & Skewness & -1.4 & 0.7 & 0.1 & -0.5 & 1.2 & 1.4 & 1.4 \\
\hline & Kurtosis & 1.8 & 1.1 & -0.5 & -0.4 & 1.0 & 1.7 & 1.6 \\
\hline \multirow[t]{7}{*}{ TOR } & Mean & 7.1 & 1.4 & 184 & 210 & 125 & 213 & 111 \\
\hline & Median & 7.1 & 1.4 & 172 & 205 & 134 & 214 & 101 \\
\hline & St. dev. & 0.3 & 0.4 & 50 & 44 & 33 & 49 & 51 \\
\hline & Max. & 7.6 & 2.4 & 310 & 335 & 172 & 300 & 308 \\
\hline & Min. & 6.4 & 0.7 & 105 & 157 & 53 & 108 & 62 \\
\hline & Skewness & 0.4 & 0.2 & 1.1 & 1.7 & -0.6 & -0.2 & 2.8 \\
\hline & Kurtosis & 0.3 & 0.4 & 1.1 & 3.0 & -0.3 & -0.3 & 9.5 \\
\hline \multirow[t]{7}{*}{ UPP } & Mean & 6.8 & 2.5 & 37 & 23 & 56 & 113 & 41 \\
\hline & Median & 6.9 & 2.7 & 37 & 22 & 42 & 102 & 32 \\
\hline & St. dev. & 0.4 & 0.9 & 9.0 & 7.0 & 44 & 42 & 33 \\
\hline & Max. & 7.7 & 3.8 & 51 & 36 & 211 & 247 & 180 \\
\hline & Min. & 5.9 & 0.4 & 15 & 9.0 & 10 & 38 & 12 \\
\hline & Skewness & -0.2 & -1.0 & -1.0 & -0.2 & 2.3 & 1.4 & 3.5 \\
\hline & Kurtosis & -0.3 & 0.6 & 1.1 & 0.5 & 6.1 & 3.5 & 14.2 \\
\hline
\end{tabular}

outlier data (Fig. 1), whereas chromium and nickel only showed a wide concentration range at site TOR (Fig. 2).

Positive skewness values $(>1)$ indicate that metal data often show large ranges extending far beyond the mean. This is also suggested in some cases by median values somewhat smaller than means. Deviations from normality are indicated by large positive values for kurtosis. These occur for one or more PTEs at all sites except SEV, and indicate that distributions of some metals are sharply peaked. In contrast, data for $\mathrm{pH}$ and organic $\mathrm{C}$ are of close to normal distribution with few exceptions. Similar behaviour was observed for samples from both depths.

\section{Comparison among sites}

Soils from both Glasgow parks had lower average $\mathrm{pH}$ values than those from other sites, especially site GL2. Both Glasgow sites were also rich in organic carbon, as was site LJU. The soils of TOR were notably richer in chromium and nickel than the other soils (minimum values 150 and $154 \mathrm{mg} \mathrm{kg}^{-1}$, respectively, for the surface and 105 and $157 \mathrm{mg} \mathrm{kg}^{-1}$ for the sub-surface samples). Only GL2 showed maximum (outlier) chromium concentrations at each depth (131 and $107 \mathrm{mg}$ $\mathrm{kg}^{-1}$ ) close to the minimum levels for TOR. Mean and median copper concentrations decrease in the order GL1 $\geq$ TOR $>$ GL2 $>$ SEV $>$ UPP $\approx$ LJU $>$ AVE for both surface samples and subsoils. Data for lead showed the order GL1 $>$ GL2 $>$ TOR $>$ SEV $>$ LJU $>$ UPP $>$ AVE at both depths. Samples from TOR and GL1 were also richest in zinc, followed by GL2, LJU, UPP and SEV. Site AVE had the lowest zinc concentrations at both depths.

A marked difference was observed between the behaviour of chromium and nickel, and of copper, lead and zinc. These 

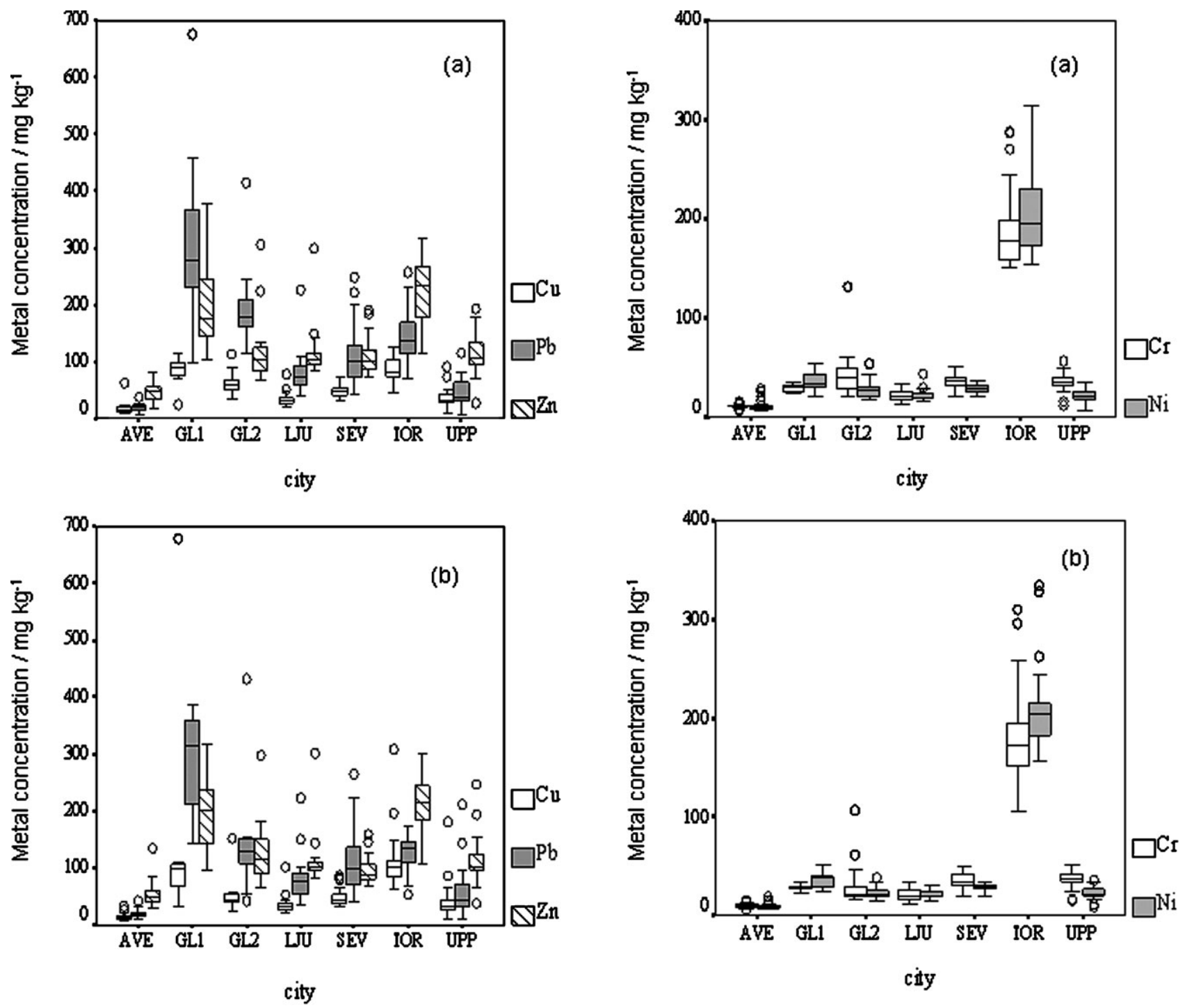

Fig. 1 Concentrations of copper, lead and zinc in (a) surface and (b) subsurface layers of the urban park soils. Boxes represent the interquartile range (IQR); dots represent outliers (values below $\mathrm{Q}_{1}-1.5 \times$ $\mathrm{IQR}$ and above $\left.\mathrm{Q}_{3}+1.5 \times \mathrm{IQR}\right)$; whiskers represent the range excluding outliers.

latter PTEs, which are amongst those referred to as "urban" in the literature, ${ }^{10,20,21}$ were present at broadly comparable levels at all sites studied, although some sites were more (GL1) or less (AVE) contaminated than others. In contrast, chromium and nickel concentrations, whilst similar at sites AVE, GL1, GL2, LJU, SEV and UPP, were notably higher at TOR. This suggests that levels of copper, lead and zinc may be controlled by one or more of various characteristics that vary gradually among the sites, e.g. age of park, road traffic density etc., whereas the high chromium and nickel concentrations in TOR are due to some peculiar characteristic of that city or park, e.g. previous industrial activity or a specific geological property. The information available is insufficient to give a definitive explanation for the high chromium and nickel levels, but a lithogenic origin is supported by the presence, in the surrounding alpine catchment, of ultramafic rocks rich in serpentinitic

Fig. 2 Concentrations of chromium and nickel in (a) surface and (b) subsurface layers of the urban park soils. Boxes represent the interquartile range $(\mathrm{IQR})$; dots represent outliers (values below $\mathrm{Q}_{1}-1.5 \times$ $\mathrm{IQR}$ and above $\mathrm{Q}_{3}+1.5 \times \mathrm{IQR}$ ); whiskers represent the range excluding outliers.

materials. ${ }^{22}$ Deposition of these rocks to constitute the alluvial plane where the city of Torino is situated might have contributed to the high chromium and nickel concentrations in the present-day soils. ${ }^{23}$ A potential anthropogenic influence, however, cannot be disregarded, as automobile manufacturing and associated metallurgical industries have been major activities in the city during the last century.

Overall, the greatest concentrations of PTE were found at sites GL1, GL2 and TOR. This is as expected given that these are amongst the longest-established parks in the study and located in cites with high population and a long legacy of heavy industry. In contrast, soils from the most recently established park, in the smallest city, contained the lowest concentrations of all the metals studied. Intermediate contamination levels were found in LJU, SEV and UPP, probably due to a variety of factors. Ljubljana is a smaller city than either 
Table 4 Maximum acceptable limits $\left(\mathrm{mg} \mathrm{kg}^{-1}\right)$ in various countries or regions applicable to soils of residential/recreational areas (unless otherwise stated)

\begin{tabular}{|c|c|c|c|c|c|}
\hline Country or region & $\mathrm{Cr}$ & $\mathrm{Ni}$ & $\mathrm{Pb}$ & $\mathrm{Zn}$ & $\mathrm{Cu}$ \\
\hline Andalucía $^{a b c}$ & $250-400 / 250-400$ & $80-200 / 100-300$ & $250-350 / 400-500$ & $300-600 / 500-1000$ & $150-300 / 300-500$ \\
\hline Canada & 64 & 50 & 140 & 200 & 63 \\
\hline Euskadi & 400 & 500 & 450 & - & - \\
\hline Italy & 150 & 120 & 100 & 150 & 120 \\
\hline Portugal $^{a b}$ & $200 / 300$ & $75 / 110$ & $300 / 450$ & $300 / 450$ & $100 / 200$ \\
\hline Québec & 250 & 100 & 500 & 500 & 100 \\
\hline Slovenia $^{a d}$ & $100 / 150 / 380$ & $50 / 70 / 210$ & $85 / 100 / 530$ & $200 / 300 / 720$ & $60 / 100 / 300$ \\
\hline Sweden $^{e}$ & 120 & 35 & 80 & 350 & 100 \\
\hline $\mathrm{UK}\left(\right.$ pre-2002) ${ }^{f}$ & $600,^{g} 1000^{h}$ & $70^{i}$ & $500,{ }^{g} 2000^{h}$ & $300^{i}$ & $130^{i}$ \\
\hline $\mathrm{UK}^{j}$ & 200 & 75 & 450 & - & - \\
\hline
\end{tabular}

${ }^{a}$ No distinction is made for any particular land use. ${ }^{b}$ Different values are given for pH below and above $7 .{ }^{c}$ "Research required" values (ranges instead of single values are given). " "Limit", "warning" and "critical" values. "KM", land with sensitive use (residential areas, kindergarten, agricultural, etc.). ${ }^{f}$ ICRCL "threshold" trigger values. ${ }^{g}$ Domestic gardens and allotments. ${ }^{h}$ Parks, playing fields and open spaces. ${ }^{i}$ Any uses where plants grow. ${ }^{j}$ Typical CLEA Soil Guideline Values.

Glasgow or Torino, and the park sampled is more recently established. Although Sevilla has a high population, the sampling site has been a public park for only 40 years. Whilst site UPP has existed as green open space since the Middle Ages, Uppsala is a relatively small city and has never supported heavy industrial activity on a scale similar to Glasgow or Torino.

\section{Comparison with recommended limits}

Table 4 provides examples of guideline values for metal contents in soil for the countries involved in the present study, or specific regions thereof. The sources and characteristics of the guideline values are also shown. Of the countries involved in URBSOIL, only Italy currently defines specific limits for PTE concentrations in soil in public recreation areas, although regional values also exist in Spain for Euskadi (the Basque Region). Whilst threshold trigger values applicable to "parks, playing fields and open spaces" were used in the UK prior to 2002 , these have now been superseded by a more sophisticated, risk-based approach. In Sweden, there exist specific limits relevant to "sensitive" land-uses (e.g. residential areas, kindergartens etc.). However, limit values established in many countries make no distinction between agricultural and urban or residential areas.

Considerable differences in allowable concentrations are found between countries and regions, even within the European Community, e.g. the limit for nickel in Sweden is considerably lower than that for Italy, whereas the opposite is true for zinc. It is evident that different conclusions concerning the status of a soil will be reached depending on which limits are considered. A further complication is the fact that some legislation specifies the analytical method to be used to obtain data, and the methods recommended in different countries are not always comparable.

Despite these limitations, some useful comparisons can be made between the European soil guideline values in Table 4 pertaining to recreational land (i.e. limit values for Italy, Sweden, Euskadi and the UK prior to 2002) and the results of the present study. Results can also be compared to relevant legislative limits used in other parts of the world. For this reason, information from Québec and Canada are also in- cluded in Table 4. These are another two of the few examples where specific limit values for soils of residential/recreational use are specified.

Many of the maximum PTE concentrations at sites in the current study exceed the guideline value of several countries, especially in the case of lead and zinc. Site TOR contains chromium and nickel concentrations above the limits of most countries, but these are seldom exceeded at other sites, except for a few samples in Glasgow, and the Swedish limit for nickel is exceeded in some SF samples from LJU and SEV. The limits for Canada, which are amongst the most restrictive, are exceeded by the maximum copper, lead and zinc concentrations at almost all sites and both depths, except for site AVE. In contrast, the Quebec and Euskadi limits are rarely exceeded.

A comparison of each site with its corresponding "official" limit values shows some interesting features. Site TOR has concentrations of all analytes (except perhaps copper) in excess of Italian limits, but only some of the soils would be considered to be unacceptably contaminated if they originated in other parts of Europe. In Glasgow, only some of the largest copper and zinc concentrations are unacceptable according to (pre-2002) UK limits, but many samples exceed limit values in other countries. Some samples at site UPP show copper and lead levels above Swedish limits, but these concentrations would be acceptable elsewhere.

Table 5 Correlation coefficients between extracted metals, organic C, and $\mathrm{pH}$ and the first two principal components, together with eigenvalues and percent of variance accounted for ${ }^{a}$

\begin{tabular}{lccl}
\hline Variates & PC 1 & PC 2 & Communalities \\
\hline $\mathrm{Ni}$ & $\mathbf{0 . 9 5 3}$ & -0.050 & 0.912 \\
$\mathrm{Cr}$ & $\mathbf{0 . 9 3 2}$ & -0.046 & 0.871 \\
$\mathrm{Zn}$ & $\mathbf{0 . 8 7 5}$ & 0.283 & 0.846 \\
$\mathrm{Cu}$ & $\mathbf{0 . 8 6 7}$ & 0.351 & 0.875 \\
$\mathrm{~Pb}$ & $\mathbf{0 . 7 0 2}$ & 0.583 & 0.833 \\
$\mathrm{Organic} \mathrm{C}$ & 0.090 & $\mathbf{0 . 8 3 0}$ & 0.697 \\
$\mathrm{pH}$ & -0.058 & $\mathbf{- 0 . 8 1 0}$ & 0.659 \\
Eigenvalue & 3.80 & 1.89 & \\
Percent variance & 54.3 & 27.0 & \\
Cumulative & 54.3 & 81.3 & \\
${ }^{a}$ Components with absolute values & $\geq 0.65$ are printed in bold. \\
\hline
\end{tabular}




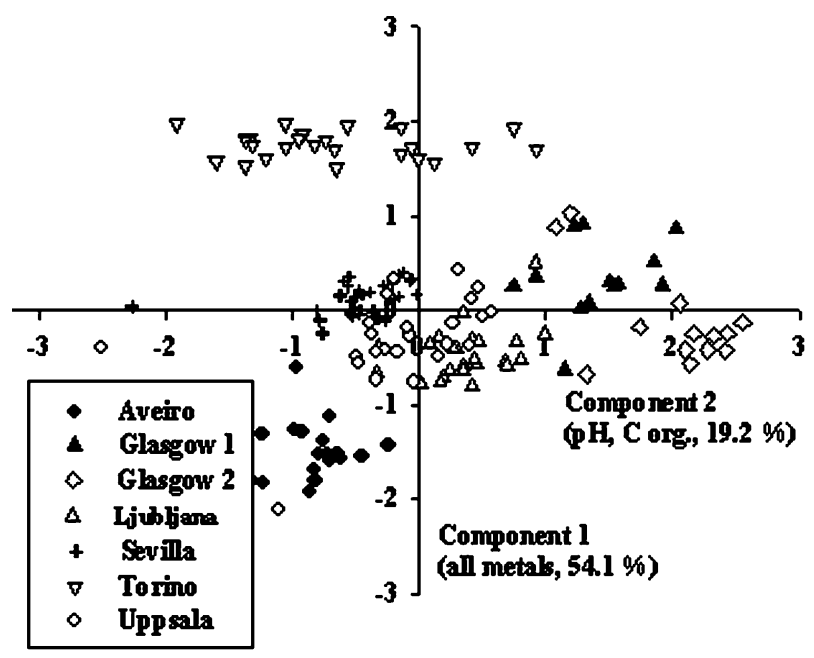

Fig. 3 Scatter of all sampling points for every site rotated on the plane of the first two principal components.

\section{Rotated principal component analysis}

Varimax rotated PCA was used to explore possible associations amongst variables at each individual site and at all sites when considered together. Due to the deviations from normality of the data, log-transformed PTE concentrations were used. Data for SF and SB sampling depths were processed separately. The discussion below is based on data for surface samples. Entirely similar conclusions were reached for the subsoils and so the data is not presented.

Table 5 shows the correlation coefficients between the various parameters measured and the first two principal components, together with eigenvalues and percent of variance accounted for. Communalities show the proportion of variance in each variable accounted for by the factors. It can be seen that all metal contents are strongly associated with one another within the first component, while $\mathrm{pH}$, organic carbon, and a portion of the lead content can be considered as represented by the second component.

Fig. 3 shows the scatter of all sampling points rotated in the plane of the first two principal components. The Glasgow soils, especially those from site GL2, are distinguished by PC 2 , showing the influence of their large organic matter content and acid $\mathrm{pH}$. Soils from TOR and AVE are located in opposite directions to one another with respect to PC 1, due to their markedly different PTE loads (high in TOR and low in AVE). The other sites (LJU, SEV and UPP) fall together in the central area of the graph.

To investigate the possibility of discriminating between sites on the basis of their PTE content, a second rotated PCA was carried our excluding the variates $\mathrm{pH}$ and organic carbon. Results are presented in Table 6 and the corresponding "loadings plot" is shown in Fig. 4. A clear difference is now evident between the "urban" metals - associated with PC 1 - and the other PTEs, associated with PC 2. Sites are ranged along the PC 1 axis according to their copper, lead and zinc contents. The high concentration of these analytes at GL1 is now noticeable, whereas it was masked in Fig. 3 because of the dominant influence of $\mathrm{pH}$ and organic carbon. The position of
Table 6 Correlation coefficients between extracted metals and the first two principal components, together with eigenvalues and percent of variance accounted for $^{a}$

\begin{tabular}{lccl}
\hline Variates & PC 1 & PC 2 & Communalities \\
\hline $\mathrm{Pb}$ & $\mathbf{0 . 9 4 9}$ & 0.222 & 0.950 \\
$\mathrm{Cu}$ & $\mathbf{0 . 8 0 8}$ & 0.507 & 0.910 \\
$\mathrm{Zn}$ & $\mathbf{0 . 7 5 9}$ & 0.542 & 0.870 \\
$\mathrm{Ni}$ & 0.372 & $\mathbf{0 . 9 1 1}$ & 0.968 \\
$\mathrm{Cr}$ & 0.321 & $\mathbf{0 . 9 3 2}$ & 0.972 \\
Eigenvalue & 2.37 & 2.30 & \\
Percent variance & 47.4 & 46.0 & \\
Cumulative & 47.4 & 93.4 &
\end{tabular}

${ }^{a}$ Components with absolute values $\geq 0.65$ are printed in bold.

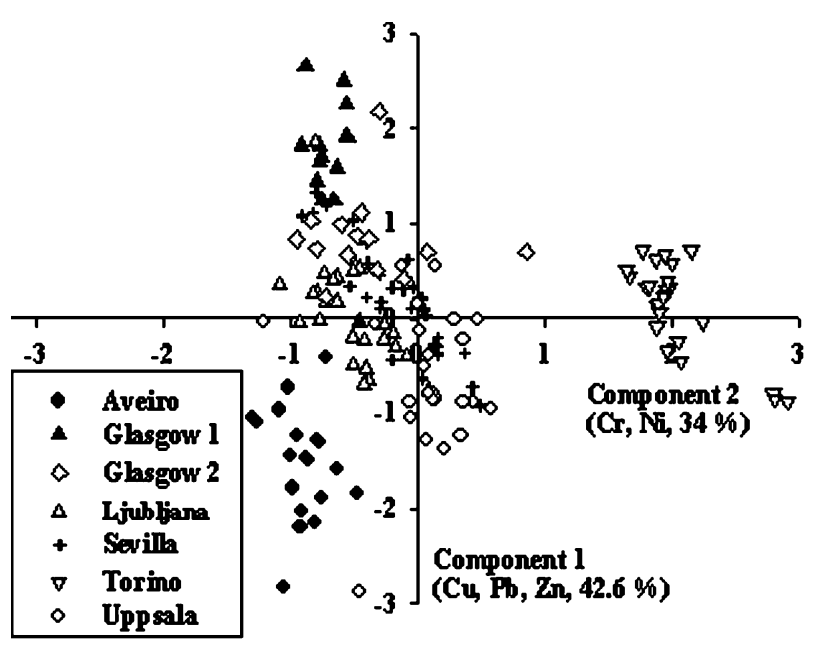

Fig. 4 Scatter of all sampling points for every site rotated on the plane of the first two principal components, excluding data for organic $\mathrm{C}$ and $\mathrm{pH}$.

the points for TOR is comparable to those for GL2, LJU, SEV and UPP with respect to PC 1, but the larger chromium and nickel concentrations give TOR a distinctly different position with respect to PC 2.

Previous work in Sevilla ${ }^{21}$ showed a strong association between urban metals and organic carbon, but this was not evident when results for several cities' parks were analysed together, perhaps because of the different origins and characteristics (degree of weathering etc.) of the soil organic matter at the different sites.

\section{Conclusions}

Application of a harmonised sampling regime has allowed comparison of concentrations of five PTEs in six parks from European cities differing markedly in their climate and geology. Wide concentrations ranges were found for some analytes. However, in terms of general contaminant status, the sites can be placed in the order (GL1, GL2, TOR) $>($ LJU, SEV, UPP) > AVE. No marked differences were found between SF and SB layers. The fact that broadly similar metal concentrations were found at sites with very different soil characteristics suggests that the general degree of "urbanisation" (age of site, industrial heritage etc.) may be more important in terms of controlling levels of metals such as 
copper, lead and zinc in urban soils than parameters such as soil $\mathrm{pH}$ or organic carbon content. Comparison of PTE concentrations with legislative guidelines was hampered by the lack of consensus in different countries of the EU, and by the fact that few limit values are specifically relevant to urban soils. These issues are amongst the challenges that must be addressed as part of the development of an integrated European soil protection strategy. The wide ranges and large standard deviations observed in the current study highlight the spatial variability of urban soil contaminants. This variability must be taken into account when planning soil surveys or in assessing the risk associated with exposure to potentially toxic elements in the urban environment.

\section{Acknowledgements}

The authors acknowledge the financial support of the European Commission for the URBSOIL research project (EVK4-CT-2001-00053). The authors from Sevilla wish to thank Mr F. J. Fernández-Farrán for help in the sampling and analytical determinations.

\section{References}

1 Towards a Thematic Strategy for Soil Protection, Communication from the Commission to the Council, the European Parliament, the Economic and Social Committee and the Committee of the Regions, Commission of the European Communities, Brussels, 2002.

2 C. R. de Kimpe and J. L. Morel, Soil Sci., 2000, 165, 31.

$3 \mathrm{~W}$. Burghardt, Proceedings of the XVII Congress of the International Soil Science Society, 14-21 August 2002, Bangkok, Thailand.

4 P. W. Abrahams, Sci. Total Environ., 2002, 291, 1.
5 C. S. C. Wang, X. Li and I. Thornton, Environ. Pollut., 2006, $142,1$.

6 M. Linde, H. Bengtsson and I. Öborn, Water, Air, Soil Pollut., 2001, 1,83.

7 D. S. Manta, M. Angelone, A. Bellanca, R. Neri and M. Sprovieri, Sci. Total Environ., 2002, 300, 229.

8 M. Imperato, P. Adamo, D. Naimo, M. Arienzo, D. Stanzione and P. Violante, Environ. Pollut., 2003, 124, 247.

9 W. Grzebisz, L. Cieśla, J. Komisarek and J. Potarzycki, Polish J. Environ. Stud., 2002, 11, 493.

10 L. Madrid, E. Díaz-Barrientos and F. Madrid, Chemosphere, 2002, 49, 1301.

11 P. Peltola and M. Åström, Environ. Geochem. Health, 2003, 25, 397.

12 J. Chronopoulos, C. Haidouti, A. Chronopoulou-Sereli and I. Massas, Sci. Total Environ., 1997, 196, 91.

13 J. R. Short, D. S. Fanning, M. S. McIntosh, J. E. Foss and J. C. Patterson, J. Soil Sci. Soc. Am., 1986, 50, 699.

14 U. Schleuss, Q. Wu and H.-P. Blume, Catena, 1998, 33, 255.

15 Personal communication, Glasgow City Council, Glasgow, UK, 2004.

16 Soil Quality - Part 3: Chemical Methods, Section 3.2 Determination of $\mathrm{pH}$, Method ISO 10390:1994, International Standards Organisation, 1994.

17 Methods of Soil Analysis: Part 2: Chemical and Microbiological Properties, ed. A. L. Page, R. H. Miller and D. R. Keeney, Agronomy Series No. 9, American Society of Agronomy, Madison, WI, 1982.

18 H. Grčman, Unpublished data, University of Ljubljana, 2004.

19 C. M. Davidson, Unpublished data, University of Strathclyde, 2005.

20 E. De Miguel, J. F. Llamas, E. Chacón, T. Berg, S. Larssen, O. Royset and M. Vadset, Atmos. Environ., 1997, 31, 2733.

21 L. Madrid, E. Díaz-Barrientos, R. Reinoso and F. Madrid, Eur. J. Soil Sci., 2004, 55, 209.

22 A. Facchinelli, E. Sacchi and L. Mallen, Environ. Pollut., 2001, 114, 313.

23 M. Biasioli, R. Barberis and F. Ajmone-Marsan, Sci. Total Environ., 2006, 356, 154. 